\title{
GMR
}

\section{Genetic effects of in vitro germination and plantlet development in chilli pepper}

\author{
P.A. Barroso ${ }^{1}$, M.M. Rêgo ${ }^{2}$, E.R. Rêgo ${ }^{2}$ and K.T.C. Ferreira ${ }^{2}$ \\ ${ }^{1}$ Laboratório de Melhoramento e Análise de Dados, \\ Departamento de Agronomia, Universidade Federal do Piauí, \\ Campus Professora Cinobelina Elvas, Bom Jesus, PI, Brasil \\ ${ }^{2}$ Laboratório de Biotecnologia Vegetal, \\ Departamento de Ciências Biológicas Universidade Federal da Paraíba, \\ Centro de Ciências Agrárias, Areia, PB, Brasil \\ Corresponding authors: P.A. Barroso / M.M. Rêgo \\ E-mail: pa.barroso@hotmail.com / mailson@cca.ufpb.br
}

Genet. Mol. Res. 16 (3): gmr16038869

Received June 8, 2017

Accepted August 21, 2017

Published September 21, 2017

DOI http://dx.doi.org/10.4238/gmr16038869

Copyright $(2017$ The Authors. This is an open-access article distributed under the terms of the Creative Commons Attribution ShareAlike (CC BY-SA) 4.0 License.

\begin{abstract}
The objective of this study was to estimate the genetic effects on in vitro germination and development of chili peppers. For this, four genotypes (UFPB-132, -134, -137, and -390) were used as parents. They were crossed in a complete diallel scheme. The parents (4) and hybrid (12) seeds were germinated in glass bottles containing MS media. The following variables were evaluated: seed germination percentage, deformed seedlings percentage, radicle emission percentage, root length, root number, hypocotyl length, hypocotyl width, definitive leaf number, leaf length, and leaf width. The data were submitted to analysis of variance and the means were grouped by the Scott-Knott criteria $(\mathrm{P} \leq 0.05)$. The diallel analysis was performed according to the Griffing method, method I, fixed model. Significant differences for all analysed variables were observed. Additive and non-additive effects were observed influencing the performance of the genotypes in relation to the evaluated variables. The genitor 132 showed the highest general combining ability for almost all evaluated characteristics, except seed
\end{abstract}

Genetics and Molecular Research 16 (3): gmr16038869 
germination percentage and deformed seedlings percentage. This study revealed dominance effects are responsible for genotypic variation for almost all evaluated traits. In addition, we found significant reciprocal effects for all studied characters. For the traits to which non-additive variances were important (germination percentage, deformed seedlings percentage, root number, hypocotyl length, hypocotyl width, and definitive leaf number, leaf length, and leaf width), there was an additional opportunity for developing $\mathrm{F}_{1}$ hybrid.

Key words: Capsicum annuum; General combining ability; In vitro recalcitrance; Specific combining ability; Tissue culture

\section{INTRODUCTION}

The Capsicum genus shows great diversity of fruit and plant types. The chili pepper agribusiness, in Brazil, involves mainly small farmers, selling the pepper fruits in natura and processed. Recently, the use of chili as ornamental plant has increased in this country (Rêgo et al., 2012). Despite this genus showing great variability, only few ornamental varieties are available in Brazilian market (Rêgo et al., 2015a). According to Neitzke et al. (2016), the great challenge of ornamental plant breeders is developing new cultivars that meet the market needs of floriculture (Neitzke et al., 2016).

In breeding programs, the choice of genitors is a critical stage. Also critical is the knowledge of genetic control of the desirable traits (Ferreira et al., 2015; Rêgo et al., 2016). The diallel analysis estimates the general and specific combining ability and other useful genetic parameters, helping the breeders in the selection of best parents and crosses (Rêgo et al., 2009, 2016; Nascimento et al., 2014).

Tissue culture techniques give support to conventional breeding programs. These techniques allow rapid multiplication, germplasm conservation and improvement of several crop species (Rolando et al., 2010). The effective use of tissue culture techniques, such as micropropagation, haploids obtaining, in vitro selection, somaclonal variation exploration, and the possibility of genes introgression, among others, depends on the capability to initiate and establish in vitro cultures (Gogoi et al., 2013; Powell and Caligari, 1987), which is directly related to the germination and development of the species.

In contrast to other species of the Solanaceae family, the in vitro propagation by seeds in pepper plants is limited by low viability and low germination rate, in addition, in interspecific crossings a low seed viability has been observed due to cross incompatibility (Nascimento et al., 2012; Gogoi et al., 2013; Rêgo et al., 2016). In these cases, tissue culture has been an alternative for regeneration of Capsicum plants. However, in vitro regeneration presents some problems as formation of rosette shoots and in vitro recalcitrance (Steinitz et al., 1999; Rêgo et al., 2016). This last one is genotype dependent so the knowledge of genetic effects of in vitro germination and development is necessary to help breeders in genotypes selection (Jinks and Pooni, 1976; Powell et al., 1985).

A common method used in a classical genetic analysis is diallel crossing applied to evaluate the combining ability of parents and progeny generations. One possible way to analyze diallel crosses is the method proposed by Griffing (1956), which divides the total genetic variance for the general combining ability (GCA) of parents and the specific combination ability (SCA) of obtained hybrids.

Genetics and Molecular Research 16 (3): gmr16038869 
The genetic bases of in vitro germination and development have been studied in other cultures such as tomatoes (Frankenberger et al., 1981), lettuce (Aslam et al., 1990), rice (Abe and Futsuhara, 1991), eggplant (Chakravarthi et al., 2010), and others. Diallelic crosses has been more used to study genetic control of morphological and agronomical traits but not to in vitro plant development for chili peppers (Rêgo et al., 2009; Schuelter et al., 2010; Nascimento et al., 2014). In a previous study, Rêgo et al. (2015b) and Medeiros et al. (2015) analyzed the germination percentage inheritance and plantlet development by Hayman's diallelic analysis.

The objective of this study was to estimate the genetic effects involved on in vitro germination and plant development in chili pepper.

\section{MATERIAL AND METHODS}

The experiment was performed at the Laboratory of Plant Biotechnology of the Universidade Federal da Paraíba (UFPB), Centro de Ciências Agrárias, in the city of Areia, PB. Four lineages of pepper plants, belonging to the Capsicum Germplasm Bank of UFPB $(132,134,137$ and 390) were used as parents and crossed in a complete diallel scheme. The crosses were performed manually using emasculated floral buds in the pre-anthesis stage. Immediately after the emasculation, the flower buds were pollinated and protected with aluminum foil capsules to prevent pollen contamination (Nascimento et al., 2012).

The seeds of the genitors (4) and their hybrids (12) were taken to a laminar flow chamber under aseptic conditions and sterilized in $100 \mathrm{~mL}$ sodium hypochlorite solution $(2 \%$ active chlorine) adding 3 drops of Tween 20, remaining immersed for $10 \mathrm{~min}$. Subsequently, they were washed three times in distilled, deionized and autoclaved water (DDA).

After disinfestation, the seeds were cut transversely on the opposite side to the germ pore using forceps and scalpel blades, as recommended by Ezura et al. (1993). Soon after, the seeds were inoculated onto $9 \mathrm{~cm}$ Petri dishes containing filter paper moistened with approximately $3 \mathrm{~mL}$ DDA water and maintained in BOD with controlled temperature of $25^{\circ}$ $\pm 2^{\circ} \mathrm{C}$ and photoperiod of $16 \mathrm{~h}$ under luminous intensity of $90 \mu \mathrm{mol} \cdot \mathrm{m}^{-2} \cdot \mathrm{s}^{-1}$ for 4 days. After this period, the seeds were transferred to glass jars containing $30 \mathrm{~mL}$ MS media (Murashigue and Skoog, 1962) with half the concentration of salts, supplemented with $30 \mathrm{~g} / \mathrm{L}$ sucrose and $8 \mathrm{~g} / \mathrm{L}$ agar and without growth regulator. The culture flasks were maintained in a growth room under fluorescent light with photoperiod of $16 \mathrm{~h}$ at $26^{\circ} \pm 2^{\circ} \mathrm{C}$ under luminous intensity of 40 $\mu \mathrm{mol} \cdot \mathrm{m}^{2} \cdot \mathrm{s}^{-1}$. On the 7 th day, the percentage of germinated seeds was analyzed, considering as germinated the seeds that presented radicle emission of at least twice the size of the seed. After 30 days, the following variables were evaluated: seed germination percentage, deformed seedlings percentage, radicle emission percentage, root length, root number, hypocotyl length, hypocotyl width, definitive leaf number, leaf length, and leaf width.

The experimental design was entirely randomized with 16 treatments (four genitors and twelve hybrids) with 10 replicates. Each repetition was composed of a flask with three seeds, totaling 30 seeds per treatment. The data were transformed by $\sqrt{ }(x+0.5)$ and then submitted to analysis of variance and the means were grouped by the Scott-Knott criteria $(\mathrm{P} \leq$ 0.05). The diallel analysis was performed according to the Griffing method (1956), method I, fixed model, which allows the obtainment of the estimates of GCA and SCA.

The statistical model used was: $Y i j=m+g i+g j+s i j+r_{i j}+$ eij, where Yij: hybrid combination average $(i \neq j)$ or parental $(i=j)$; $m$ : general average; $g_{i}$, e $g_{j}$ : effects of general combining ability of ith and parental $j$ th $(i, j=1,2 \ldots p)$; $s_{i j}$ : effect of specific combining

Genetics and Molecular Research 16 (3): gmr16038869 
ability for the crosses between $\mathrm{i}$ and $\mathrm{j}$ order parental; $\mathrm{r}_{\mathrm{ij}}$ : reciprocal effect which measures the differences afforded by the $\mathrm{i}$ or $\mathrm{j}$ parental, when used as male or female in $\mathrm{ij}$ crossing; $\mathrm{e}_{\mathrm{ij}}$ : average experimental error, associated with the observation of $\mathrm{jk}$ order $(\mathrm{k}=1, \ldots, \mathrm{r}), \mathrm{r}$ being the number of repetitions.

The F test was used to evaluate the significant differences of GCA, SCA, and reciprocal effect. For the comparison of $\hat{\mathrm{g}}_{\mathrm{i}}, \hat{\mathrm{S}}_{\mathrm{ij}}$, and $\hat{\mathrm{R}}_{\mathrm{ij}}$, the $\mathrm{t}$ test was performed. All statistical analyses were performed using the Genes computer software (Cruz, 2006).

\section{RESULTS}

Significant differences among genotypes for all variables $(\mathrm{P} \leq 0.01)$ were observed (Table 1). The genotypes showed high germination percentage above $50 \%$. Two groups were formed for this trait. The first group showed germination percentage from $51.62(390 \times 137)$ to $67.19 \%(137)$. The second one ranged from $77.57 \%$ (390 x 132) to $93.80 \%$ (134 x 132). Among the parents, only UFPB-137 presented low germination percentage (67.19) (Table 2). All genotypes showed considerable percentage of deformed seedlings (Figure 1A and B). The parents 132, 134, 137, and 390 and the hybrid combinations 134 × 132, 134 x 137, 137 x 390, and 137 x 134 reciprocal showed the highest percentage of deformed seedlings ranging from $62.51 \%(137 \times 390)$ to $86.54 \%(134 \mathrm{x}$ $132)$, forming the first group. The other hybrids formed the second group with a low percentage of deformed plants ranging from $37.79 \%$ (390 x 134) to 57.67\% (390 x 132) (Table 2).

Table 1. Summary of analysis of variance for evaluated in vitro germination and plantlet development in chili pepper (Capsicum annuum L.).

\begin{tabular}{l|c|c|c|c|c|c|c|c|c|c}
\hline \multirow{2}{*}{ S.V } & \multicolumn{9}{|c}{ Q.M. } \\
\cline { 2 - 11 } & $\mathrm{G}$ & $\mathrm{DS}$ & $\mathrm{RE}$ & $\mathrm{RL}$ & $\mathrm{RN}$ & $\mathrm{HL}$ & $\mathrm{HW}$ & $\mathrm{LN}$ & LL & LW \\
\hline Treatment & $2026.13^{* *}$ & $2040.32^{* *}$ & $2686.84^{* *}$ & $2.3^{* *}$ & $7.29^{* *}$ & $1.78^{* *}$ & $0.002^{* *}$ & $2.53^{* *}$ & $0.2^{* *}$ & $0.11^{* *}$ \\
\hline General Average & 73.31 & 60.3 & 56.82 & 1.22 & 1.54 & 1.05 & 0.72 & 1.23 & 0.87 & 0.83 \\
\hline Variation Coefficient (\%) & 26.72 & 33.53 & 29.37 & 39.12 & 59.07 & 53.03 & 3.99 & 69.23 & 29.48 & 24.11 \\
\hline
\end{tabular}

Germinated seeds percentage $(\mathrm{G})$, deformed seedlings percentage (DS), radicle emission percentage (RE), root length (RL), root number (NR), hypocotyl length (HL), hypocotyl width (HW), definitive leaf number (LN), leaf length (LF), and leaf width (LW). **Significant at $1 \%$ probability by the $\mathrm{F}$ test.

Table 2. Average of 10 quantitative characteristics of germination and in vitro development evaluated in four parents and twelve hybrids of chili pepper (Capsicum annuиm L.).

\begin{tabular}{l|c|c|c|c|c|c|c|c|c|c}
\hline Genotype & G & DS & RE & RL & RN & HL & HW & LN & LL & LW \\
\hline 132 & $81.89 \mathrm{a}$ & $80.67 \mathrm{a}$ & $62.87 \mathrm{~b}$ & $1.42 \mathrm{~b}$ & $1.37 \mathrm{c}$ & $1.14 \mathrm{~b}$ & $0.74 \mathrm{a}$ & $1.28 \mathrm{~b}$ & $0.92 \mathrm{~b}$ & $0.86 \mathrm{~b}$ \\
\hline $132 \times 134$ & $87.27 \mathrm{a}$ & $42.46 \mathrm{~b}$ & $40.57 \mathrm{c}$ & $0.78 \mathrm{c}$ & $0.96 \mathrm{c}$ & $0.81 \mathrm{~b}$ & $0.71 \mathrm{~b}$ & $1.06 \mathrm{~b}$ & $0.78 \mathrm{~b}$ & $0.76 \mathrm{~b}$ \\
\hline $132 \times 137$ & $61.65 \mathrm{~b}$ & $55.07 \mathrm{~b}$ & $52.66 \mathrm{c}$ & $1.01 \mathrm{c}$ & $1.12 \mathrm{c}$ & $0.98 \mathrm{~b}$ & $0.71 \mathrm{~b}$ & $1.11 \mathrm{~b}$ & $0.89 \mathrm{~b}$ & $0.84 \mathrm{~b}$ \\
\hline $132 \times 390$ & $55.43 \mathrm{~b}$ & $48.85 \mathrm{~b}$ & $40.55 \mathrm{c}$ & $0.74 \mathrm{c}$ & $0.76 \mathrm{c}$ & $0.71 \mathrm{c}$ & $0.71 \mathrm{~b}$ & $0.71 \mathrm{~b}$ & $0.71 \mathrm{~b}$ & $0.71 \mathrm{~b}$ \\
\hline $134 \times 132$ & $93.80 \mathrm{a}$ & $86.54 \mathrm{a}$ & $87.25 \mathrm{a}$ & $1.93 \mathrm{a}$ & $2.30 \mathrm{~b}$ & $1.07 \mathrm{~b}$ & $0.74 \mathrm{a}$ & $1.3 \mathrm{~b}$ & $0.92 \mathrm{~b}$ & $0.94 \mathrm{a}$ \\
\hline 134 & $85.70 \mathrm{a}$ & $71.68 \mathrm{a}$ & $62.87 \mathrm{~b}$ & $1.26 \mathrm{~b}$ & $1.64 \mathrm{c}$ & $0.94 \mathrm{~b}$ & $0.74 \mathrm{a}$ & $1.11 \mathrm{~b}$ & $0.86 \mathrm{~b}$ & $0.86 \mathrm{~b}$ \\
\hline $134 \times 137$ & $66.68 \mathrm{~b}$ & $65.11 \mathrm{a}$ & $57.84 \mathrm{c}$ & $1.16 \mathrm{~b}$ & $1.65 \mathrm{c}$ & $1.03 \mathrm{~b}$ & $0.72 \mathrm{~b}$ & $1.35 \mathrm{~b}$ & $0.85 \mathrm{~b}$ & $0.8 \mathrm{~b}$ \\
\hline $134 \times 390$ & $65.11 \mathrm{~b}$ & $49.90 \mathrm{~b}$ & $45.22 \mathrm{c}$ & $0.91 \mathrm{c}$ & $1.16 \mathrm{c}$ & $0.99 \mathrm{~b}$ & $0.72 \mathrm{~b}$ & $1.33 \mathrm{~b}$ & $0.89 \mathrm{~b}$ & $0.83 \mathrm{~b}$ \\
\hline $137 \times 132$ & $62.34 \mathrm{~b}$ & $45.22 \mathrm{~b}$ & $43.32 \mathrm{c}$ & $0.90 \mathrm{c}$ & $1.07 \mathrm{c}$ & $0.90 \mathrm{~b}$ & $0.72 \mathrm{~b}$ & $1.11 \mathrm{~b}$ & $0.85 \mathrm{~b}$ & $0.81 \mathrm{~b}$ \\
\hline 137 & $90.68 \mathrm{a}$ & $71.68 \mathrm{a}$ & $83.77 \mathrm{a}$ & $1.99 \mathrm{a}$ & $3.58 \mathrm{a}$ & $2.08 \mathrm{a}$ & $0.75 \mathrm{a}$ & $2.23 \mathrm{a}$ & $1.16 \mathrm{a}$ & $1.02 \mathrm{a}$ \\
\hline $137 \times 390$ & $67.19 \mathrm{~b}$ & $62.87 \mathrm{a}$ & $54.21 \mathrm{c}$ & $1.09 \mathrm{~b}$ & $1.39 \mathrm{c}$ & $1.04 \mathrm{~b}$ & $0.73 \mathrm{~b}$ & $1.12 \mathrm{~b}$ & $0.87 \mathrm{~b}$ & $0.83 \mathrm{~b}$ \\
\hline $390 \times 132$ & $85.32 \mathrm{a}$ & $62.51 \mathrm{a}$ & $77.57 \mathrm{a}$ & $2.09 \mathrm{a}$ & $3.33 \mathrm{a}$ & $2.06 \mathrm{a}$ & $0.76 \mathrm{a}$ & $2.49 \mathrm{a}$ & $1.19 \mathrm{a}$ & $1.06 \mathrm{a}$ \\
\hline $390 \times 134$ & $54.21 \mathrm{~b}$ & $57.67 \mathrm{~b}$ & $40.55 \mathrm{c}$ & $0.79 \mathrm{c}$ & $0.79 \mathrm{c}$ & $0.71 \mathrm{~b}$ & $0.71 \mathrm{~b}$ & $0.71 \mathrm{~b}$ & $0.71 \mathrm{~b}$ & $0.71 \mathrm{~b}$ \\
\hline $390 \times 137$ & $51.62 \mathrm{~b}$ & $50.76 \mathrm{~b}$ & $37.79 \mathrm{c}$ & $0.71 \mathrm{c}$ & $0.71 \mathrm{c}$ & $0.71 \mathrm{c}$ & $0.71 \mathrm{~b}$ & $0.71 \mathrm{~b}$ & $0.71 \mathrm{~b}$ & $0.71 \mathrm{~b}$ \\
\hline 390 & $85.54 \mathrm{a}$ & $76.00 \mathrm{a}$ & $74.09 \mathrm{a}$ & $0.96 \mathrm{c}$ & $1.17 \mathrm{c}$ & $0.71 \mathrm{~b}$ & $0.71 \mathrm{~b}$ & $0.71 \mathrm{~b}$ & $0.71 \mathrm{~b}$ & $0.71 \mathrm{~b}$ \\
\hline
\end{tabular}

Germination seed percentage (G), deformed seedlings percentage (DS), radicle emission percentage (RE), root length (RL), root number (NR), hypocotyl length (HL), hypocotyl width (HW), definitive leaf number (LN), leaf length (LF), and leaf width (LW). Means followed by the same letter in the column do not differ statistically by the Skott-Knott test at $5 \%$ probability.

Genetics and Molecular Research 16 (3): gmr16038869 

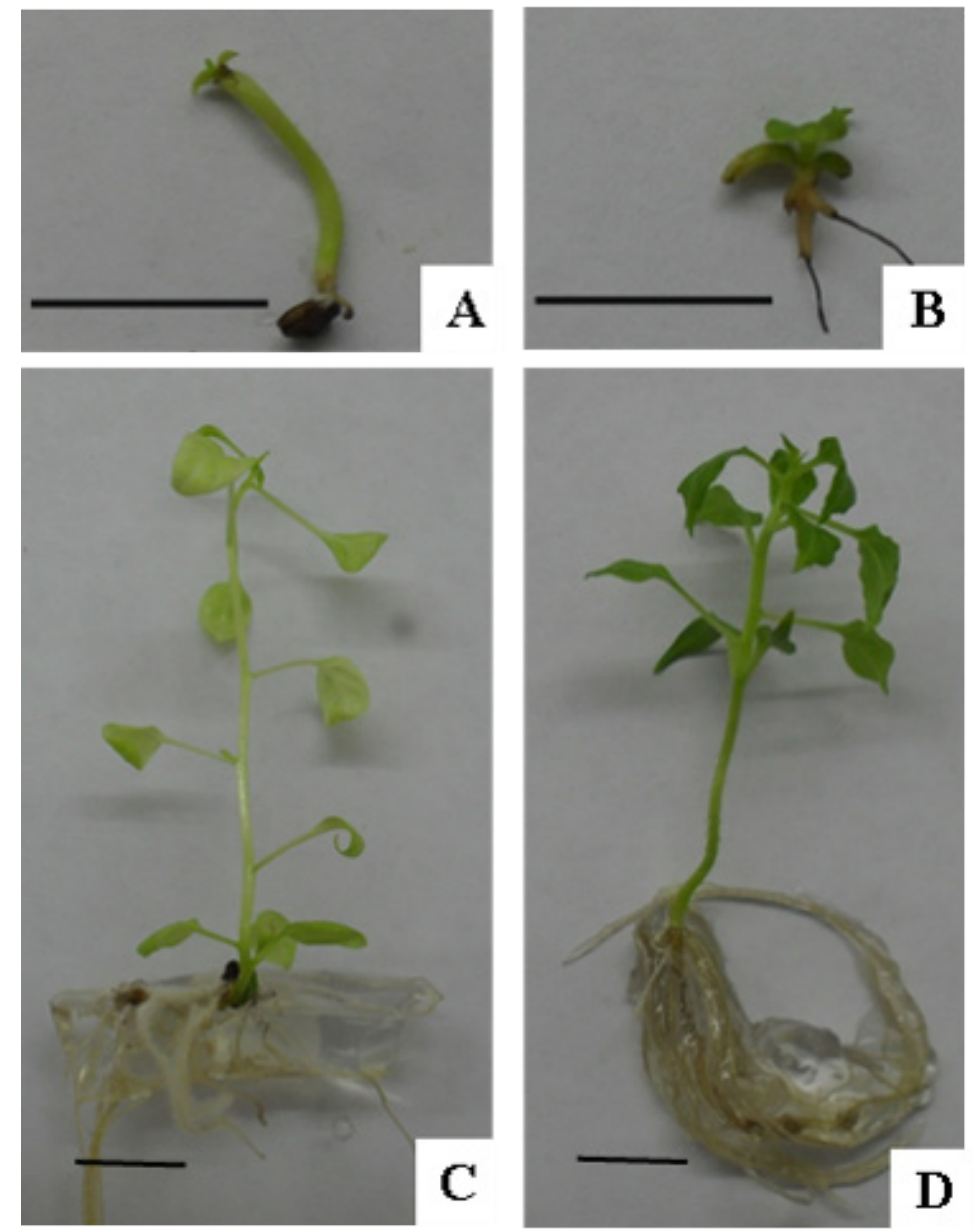

Figure 1. In vitro germination and development of ornamental pepper (Capsicum annuum L.). A. and B. Deformed seedlings; C. hybrid 132 x 134; D. reciprocal 137 x 134. Bar $=1 \mathrm{~cm}$.

The highest values for radicle emission percentage and root length were found in the following genotypes: 134 x 132, 137 x 134, 137 x 390, and 390. Both variables were grouped into three groups (Table 2). Regarding the root number and hypocotyl length, the genotypes with highest values were $137 \times 134$ and 137 x 390 hybrids (Table 2).

In regards to hypocotyl width, the hybrids (134 x 132, 137 x 134, and $137 \times 390)$ and the parents (132 and 134) showed the highest values for this character $(0.74$ to $0.76 \mathrm{~mm})$ (Table 2). For leaf number, length, and width, the best hybrid combinations were 137 x 134 and 137 x 390. Besides these combinations, pertaining to leaf width, the reciprocal cross 134 $\mathrm{x} 132$ does not differ from the previously mentioned ones.

According to the quadratic components of GCA and reciprocal effect were significant for all evaluated traits. There was significance to SCA, for all characters except to root length (Table 3).

Genetics and Molecular Research 16 (3): gmr16038869 
Table 3. Analysis of variance of the estimates of the quadratic components associated with the effects of general combining ability $\left(\hat{\Phi}^{2} g\right)$ and specific combining ability $\left(\hat{\Phi}^{2} s\right)$ and the reciprocal $\left(\hat{\Phi}^{2} r e\right)$ evaluated in vitro germination and development in chili pepper (Capsicum annuum L.).

\begin{tabular}{l|c|c|c|c|c|c|c|c|c|c}
\hline S.V & G & DS & RE & RL & RN & HL & HW & LN & LL & LW \\
\hline GCA & $2614.60^{* *}$ & $8768.993^{* *}$ & $8073.13^{* *}$ & $8.3970^{* *}$ & $7.32^{* *}$ & $4.68^{* *}$ & $0.01^{* *}$ & $14.41^{* *}$ & $1.953^{* *}$ & $1.162^{*}$ \\
\hline SCA & $8760.12^{* *}$ & $4205.12^{* *}$ & $848.80^{* *}$ & $0.370^{\mathrm{ns}}$ & $2.30^{*}$ & $2.25^{* *}$ & $0.004^{* *}$ & $6.34^{* *}$ & $0.562^{* *}$ & $0.333^{* *}$ \\
\hline Reciprocal & $4445.34^{* *}$ & $3061.82^{* *}$ & $4578.37^{* *}$ & $5.75^{* *}$ & $8.79^{* *}$ & $5.33^{* *}$ & $0.011^{* *}$ & $14.68^{* *}$ & $1.05^{* *}$ & $0.57^{* *}$ \\
\hline$\widehat{\Phi}^{2} g$ & 27.884599 & 104.49912 & 97.432481 & 0.102097 & 0.081159 & 0.054691 & 0.000225 & 0.171056 & 0.023591 & 0.014032 \\
\hline$\widehat{\Phi}^{2} s$ & 837.628906 & 379.6065 & 57.026083 & 0.014036 & 0.146907 & 0.194855 & 0.000307 & 0.562079 & 0.049646 & 0.029281 \\
\hline$\widehat{\Phi}^{2} r e$ & 203.075458 & 132.6381 & 214.9916 & 0.276344 & 0.398178 & 0.251013 & 0.000524 & 0.697808 & 0.049569 & 0.02667 \\
\hline$\widehat{\Phi}^{2} g / \widehat{\Phi}^{2} s$ & 0.03328 & 0.27528 & 1.708559 & 7.273938 & 0.552451 & 0.280675 & 0.732899 & 0.304327 & 0.475184 & 0.526134 \\
\hline
\end{tabular}

Germination seed percentage (G), deformed seedlings percentage (DS), radicle emission percentage (RE), root length (RL), root number (NR), hypocotyl length (HL), hypocotyl width (HW), definitive leaf number (LN), leaf length (LF), and leaf width (LW). **Significant at $1 \%$ probability. *Significant at $5 \%$ probability by the $\mathrm{F}$ test. ns $=$ not significant.

The additive gene ratio effects were superior to the dominant ones in radicle emission (1.708559) and root length (7.273938). On the other hand, $\Phi^{2} g / \Phi^{2} s$ ratio values were below than 1 for the remaining traits. This shows the importance of non-additive effects controlling these characters (Table 3 ).

The GCA effects estimates ( $\hat{i}$ i) presented significant positive and negative values in all studied traits (Table 4). The genitor 134 presented significant and positive values for germination percentage (6.1406). This same genitor presented negative and significant $\hat{g} i$ value $(-8.5375)$ for the deformed seedlings percentage.

Table 4. Estimates of general combining ability $(\hat{g} i)$ for in vitro germination and development chili pepper (Capsicum annuum L.).

\begin{tabular}{l|c|c|c|c|c|c|c|c|c|c|c}
\hline Parents & G & DS & RE & RL & RN & HL & HW & LN & LL & LW \\
\hline 132 & -2.6818 & $12.855^{* *}$ & $12.2185^{* *}$ & $0.3956^{* *}$ & $0.19^{*}$ & $0.2312^{* *}$ & $0.018^{* *}$ & $0.22^{* *}$ & $0.0837^{* *}$ & $0.0543^{* *}$ \\
\hline 134 & $6.1406^{* *}$ & $-8.5375^{* *}$ & $-6.3787^{* *}$ & $-0.1743^{* *}$ & 0.0525 & 0.0737 & -0.0012 & 0.0637 & -0.0287 & -0.0268 \\
\hline 137 & 3.1268 & $4.22^{*}$ & $3.9975^{*}$ & $0.1168^{*}$ & $0.2^{*}$ & 0.035 & 0.0012 & $0.3312^{* *}$ & $0.1512^{* *}$ & $0.1268^{* *}$ \\
\hline 390 & $-6.5856^{* *}$ & $-8.5375^{* *}$ & $-9.8375^{* *}$ & $-0.3381^{* *}$ & $-0.4425^{* *}$ & $-0.34^{* *}$ & $-0.0187^{* *}$ & $-0.615^{* *}$ & $-0.2062^{* *}$ & $-0.1543^{* *}$ \\
\hline
\end{tabular}

Germination seed percentage (G), deformed seedlings percentage (DS), radicle emission percentage (RE), root length (RL), root number (NR), hypocotyl length (HL), hypocotyl width (HW), definitive leaf number (LN), leaf length (LF), and leaf width (LW). **, ${ }^{*}$ Significant at 1 and $5 \%$ probability, respectively, by the $t$-test.

The $\hat{\mathrm{S}}_{\mathrm{ij}}$ and $\hat{\mathrm{R}}_{i j}$ effects were significant to germination percentage for all hybrids, except $132 \times 390,134$ x 137, $137 \times 132$, and $390 \times 137$ (Table 5). Based on the $\hat{\mathrm{S}}_{\mathrm{ij}}$ and $\hat{\mathrm{R}}_{i j}$ effects, the most favorable combinations for reduction of deformed seedlings percentage were: hybrid 132 x $134(-11.77)$ and 137 x $390(-16.97)$.

For the root characteristics, the best hybrids combinations were $134 \times 132,137 \times$ $132,390 \times 132$, and $137 \times 134$. The hybrid $132 \times 134(+0.48)$ showed the major SCA effects values for hypocotyl length, as well as the 137 x 132 and 137 x 134 (Figure 1C). For hypocotyl diameter the best combinations were $134 \times 132(+0.04)$ and $137 \times 132(+0.03)$. To number, length and diameter of leaves, the best combinations were $134 \times 132,137 \times 132$, and $137 \mathrm{x}$ 134 (Figure 1D).

Genetics and Molecular Research 16 (3): gmr16038869 
Table 5. Estimates of specific combining effects and their reciprocal effects for in vitro germination and development of chili pepper (Capsicum annuиm L.).

\begin{tabular}{|c|c|c|c|c|c|c|c|c|c|c|}
\hline Genotypes & \multicolumn{2}{|c|}{$\mathrm{G}$} & \multicolumn{2}{|c|}{ DS } & \multicolumn{2}{|c|}{$\mathrm{RE}$} & \multicolumn{2}{|c|}{ RL } & \multicolumn{2}{|c|}{$\mathrm{RN}$} \\
\hline $132 \times 134$ & $-24.96 * *$ & $13.835^{* *}$ & $-11.77 * *$ & $13.83^{* *}$ & 1.84 & $23.36^{* * *}$ & 0.03 & $0.7 * *$ & 0.22 & 0.97 ** \\
\hline $132 \times 137$ & $10.93^{* *}$ & 0 & -1.17 & $9.52 *$ & 5.3 & $9.52 *$ & 0.068 & $0.95 * *$ & -0.2 & 0.18 \\
\hline $132 \times 390$ & -2.71 & $23.36^{* *}$ & -2.25 & $23.36^{* *}$ & 5.3 & $23.36^{* * *}$ & -0.07 & $0.42 * *$ & 0.001 & 0.25 \\
\hline $134 \times 137$ & 0.33 & $17.27 * *$ & $20.21 * *$ & $9.52 *$ & 0.5387 & $13.83^{* * *}$ & -0.006 & $0.38 * *$ & $0.5^{* *}$ & $1.26 * *$ \\
\hline $134 \times 390$ & $10.044 * *$ & $17.27 * *$ & -4.22 & 0 & 0.5387 & 0 & 0.068 & 0 & -0.11 & 0 \\
\hline \multirow[t]{2}{*}{$137 \times 390$} & $-31.88^{* *}$ & 0 & $-16.97 * *$ & 0 & -9.83 & 0 & $-0.22 *$ & 0 & -0.26 & 0 \\
\hline & \multicolumn{2}{|c|}{$\mathrm{HL}$} & \multicolumn{2}{|c|}{ HW } & \multicolumn{2}{|c|}{ LN } & \multicolumn{2}{|c|}{ LL } & \multicolumn{2}{|c|}{ LW } \\
\hline $132 \times 134$ & $0.48^{* *}$ & 1.12 & 0.003 & $0.04 * *$ & 0.02 & $0.92 * *$ & 0.08 & $0.34 * *$ & $0.07 *$ & $0.26 * *$ \\
\hline $132 \times 137$ & $-0.37 * *$ & $0.23 * *$ & -0.008 & $0.03 * *$ & $-0.58 * *$ & $0.58 * *$ & $-0.18 * *$ & $0.25 * *$ & $-0.13^{* * *}$ & $0.2^{* *}$ \\
\hline $132 \times 390$ & $-0.23 *$ & 0 & -0.01 & 0 & -0.22 & 0 & -0.08 & 0 & -0.05 & 0 \\
\hline $134 \times 137$ & 0.08 & $0.53 * *$ & 0.01 & $0.03 * *$ & $0.78 * *$ & $1.79 * *$ & 0.036 & $0.36^{* *}$ & -0.004 & $0.25 * *$ \\
\hline $134 \times 390$ & -0.07 & 0 & 0.001 & 0 & -0.06 & 0 & 0.02 & 0 & 0.02 & 0 \\
\hline $137 \times 390$ & -0.03 & 0 & -0.001 & 0 & $-0.33 *$ & 0 & $-0.15^{* *}$ & 0 & $-0.12^{* * *}$ & 0 \\
\hline
\end{tabular}

Germination seed percentage (G), deformed seedlings percentage (DS), radicle emission percentage (RE), root length (RL), root number (NR), hypocotyl length (HL), hypocotyl width (HW), definitive leaf number (LN), leaf length (LF), and leaf width (LW). ${ }^{* *}$ Significant at $1 \%$ probability by the $t$-test. *Significant at $5 \%$ probability, by the $t$-test.

\section{DISCUSSION}

There were significant differences among genotypes for all evaluated traits. This variability allows to select responsive genotypes and to insert this trait by backcross in commercial varieties. Desbrunais et al. (1992) also found distinguishable genotypic effects in coffee. These authors highlighted the importance of this variability to slow growth conditions for the storage of coffee shoots cultured in vitro.

According to Hatzig et al. (2015), seed germination was influenced by genetic and environmental factors. In pepper, for example, the germination is affected for temperature stresses (Guo et al., 2012). Since the experiment was conducted in controlled environment, the response found was due the genotypic differences. The parents showed different behavior for germination. The hybrids, 137 x 134 and 137 x 390, showed heterosis for seed germination although the cross involves a parent with low seed germination rate (137). In this case, the exploitation of hybrids was recommended. Rapid and uniform seed germination is a crucial prerequisite for crop establishment in vitro. Rêgo et al. (2015b) studying seed germination in vitro of chili peppers found dominance effects in this trait. In a generation analysis performed gerboxes in BOD, in C. annuum, Barroso et al. (2015) also observed predominance of nonadditive effects considering analysis of the parameters of the additive-dominant model, also concluding on a heterosis, confirming the finds in this study.

For several authors, the morphogenetic recalcitrance in pepper plants is one of the major problems of tissue culture. This limits procedures such as genetic engineering (OchoaAlejo and Ramirez Malagon, 2001; Mok and Norzulaani, 2007, Rêgo et al., 2016). Parents and hybrids showing high percentage of deformed seedlings should not be used, despite having a high seed germination rate. The hybrids $132 \times 134$ and $390 \times 132$, on the other hand, should be selected, since they showed high seed germination percentage and low percentage of deformed seedlings. The negative heterosis found in the hybrids for deformed seedlings percentage should be explored in breeding programs to break in vitro recalcitrance. The range of seed germination found in this study (51.62 to 93.80) was higher than those found by Rêgo et al. (2015b) (16.66 to 86.66) working with these same parents. Despite the low germination rate, these authors showed the same genetic effects reported in this research.

Genetics and Molecular Research 16 (3): gmr16038869 
All hybrids presented positive heterosis for radicle emission percentage, root length, root number, hypocotyl length, hypocotyl diameter, definitive leaf number, leaf length, and leaf width. This demonstrates the potential to introduce development ability into recalcitrant lines by hybridization. Pratta et al. (2003) and Sparrow et al. (2004), working with tomato and brassicas, respectively, found similar results in an in vitro diallel analysis. In this study, it is recommended to use hybrids $137 \times 134$ and $137 \times 390$, since they showed the highest values for all these traits, with well-developed seedlings. On the other hand, the hybrids with less developed seedlings (132 x 390 and 390 x 134) should not be discarded, because for germplasm conservation (George, 1993) in short-term and medium-term storage, the aim is to reduce growth and to increase the intervals between subcultures (Engelmann 2011).

This study revealed dominance effects are responsible for genotypic variation for almost all evaluated traits. In addition, we found significant reciprocal effects for all studied characters. According to by Rêgo et al. (2009) and Nascimento et al. (2014), in the traits where non-additive variances were important (germination percentage, deformed seedlings percentage, root number, hypocotyl length, hypocotyl width, definitive leaf number, leaf length and leaf width), there was an additional opportunity for developing $\mathrm{F}_{1}$ hybrid.

For radicle emission percentage and root length, since additive variances were found to be important in the genetic control of root traits, the use of population improvement method in the form of diallel selective mating, recurrent selection or mass selection might lead to release new varieties with higher values for these traits. The results of this study clearly show that non-recalcitrant varieties can be developed through hybrid breeding in C. annuит. Medeiros et al. (2015) found similar data in a Hayman diallel analysis.

The parent 134 is ideal for the in vitro establishment, considering the variables germination percentage and deformed seedlings and based on $\hat{\mathrm{g}}_{\mathrm{i}}$ values. In the majority of the cases, good general combiners showed better mean performance (Rêgo et al., 2009). Then, the parents may be selected either on the basis of $\hat{g}_{i}$ values, mean performance or a combination of both.

The genitors 132 and 137 present high development ability with significant positive values for radicle emission, root length, roots numbers, hypocotyl length, hypocotyl diameter, leaf number, leaf length, and leaf width. Although these parents showed no good germination, they present good general combining ability and should be used in hybrid combinations in order to increase production of normal seedlings. Hazarika (2003) and Chandra et al. (2010) highlighted the importance of well-developed in vitro seedlings to establish the culture during the acclimatization. In addition, more developed seedlings have higher biomass, which will serve as a source of explants for micropropagation and as a carbon source to be consumed by the emergence of new leaves (Rolland et al. 2002). On the other hand, if the aim is germplasm in vitro conservation the parent 390 contributes significantly to favorable alleles diminishing the seedling development. According to Roca et al. (1991) and George (1993), this is desired to maximize the period of subculture. The hybrids including this genitor $(132 \times 390$ and $390 \mathrm{x}$ 134) also have the lowest means for hypocotyl length.

Significant SCA effects observed in this work indicate the deviation from hybrid value compared with parents values. Hybrids with significantly positive estimates should be selected to increase the evaluated character. The results suggest the possibility of exploiting the hybrid vigor for all characters studied in this research. According to Griffing (1956), the hybrids with high specific combining ability effects, and being involved in at least one parent with high or average GCA effects for a particular trait is a good strategy for plant breeding. For the percentage of deformed seedlings, however, hybrid combinations with significant negative

Genetics and Molecular Research 16 (3): gmr16038869 
values are desired since it will reduce the number of deformed seedlings. Hybrids as $132 \mathrm{x} 134$ and $137 \times 390$ are suitable for this purpose, with the normal development after germination (Figure 1C and D).

The reciprocal hybrids presented almost all significant values showing great importance of maternal effects to the control of these characteristics. The underlying genetic basis of the reciprocal differences for in vitro response could be cytoplasmic factors (e.g., mtDNA), physiological characteristics of maternal plants, or segregation of nuclear factors of a maternal parent (Lazar et al. 1984). These effects have already been determined for other traits such callus production in eggplant (Chakravarthi et al., 2010), sprouts regeneration in lettuce (Sparrow et al., 2004), and organogenesis from Helianthus embryos (Sarrafi et al., 1996). Based on these results, it is possible to detect the predominance of non-additive effects on the determination of evaluated characters. In this case, the exploitation of hybrids is indicated.

\section{REFERENCES}

Abe T and Futsuhara Y (1991). Diallel analysis of callus growth and plant regeneration in rice seed callus. Jpn. J. Genet. 66: 129-140. https://doi.org/10.1266/jig.66.129

Aslam FN, MacDonald MV, Loudon P and Ingram DS (1990). Rapid cycling Brassica species; inbreeding and selection of B. campestris for anther culture ability. Ann. Bot. 65: 557-566. https://doi.org/10.1093/oxfordjournals.aob.a087969

Barroso PA, dos Santos Pessoa AM, Medeiros GDA, da Silva Neto JJ, et al. (2015). Genetic control of seed germination and physiological quality in ornamental pepper. Acta Horticult. 1087: 409-413.

Chakravarthi DVN, Rao YV, Rao MVS and Manga V (2010). Genetic analysis of in vitro callus and production of multiple shoots in eggplant. Plant Cell Tissue Organ Cult. 102: 87-97. https://doi.org/10.1007/s11240-010-9709-5

Chandra S, Bandopadhyay R, Kumar V and Chandra R (2010). Acclimatization of tissue cultured plantlets: from laboratory to land. Biotechnol. Lett. 32: 1199-1205. https://doi.org/10.1007/s10529-010-0290-0

Cruz CD (2006) Programa Genes (Versão Windows): aplicativo computacional em genética e estatística. Editora UFV, Universidade Federal de Viçosa, Viçosa.

Desbrunais A, Noirot M and Charrier A (1992). Slow growth in vitro conservation of coffee (Coffea spp.). Plant Cell Tissue Organ Cult. 31: 105-110. https://doi.org/10.1007/BF00037693

Engelmann F (2011). Use of biotechnology for conservation of plant biodiversity. In Vitro Cell. Dev. Biol. Plant 47: 5-16. https://doi.org/10.1007/s11627-010-9327-2

Ezura H, Nishimiya S and Kasumi M (1993). Efficient regeneration of plants independent of exogeneous growth regulators in bell pepper (Capsicum annumm L.). Plant Cell Rep. 12: 676-680. https://doi.org/10.1007/BF00233418

Ferreira KTC, Rêgo ER, Rêgo MM, Fortunato FLG, et al. (2015). Combining Ability for Morpho-Agronomic Traits in Ornamental Pepper. Acta Hortic. 187-194. https://doi.org/10.17660/ActaHortic.2015.1087.22

Frankenberger A, Hasegawa PM and Tigchelaar EC (1981). Diallel analysis of shoot-forming capacity among selected tomato genotypes. Z. Pflanzenphysiol. 102: 233-242. https://doi.org/10.1016/S0044-328X(81)80225-5

George EF (1993). Plant propagation by tissue culture. 2. ed. Exegetics, London.

Gogoi S, Acharjee S and Devi J (2013). In vitro plantlet regeneration of Capsicum chinense Jacq. cv. 'Bhutjalakia': hottest chili of northeastern India. In Vitro Cell. Dev. Biol. Plant 50: 235-241.

Griffing B (1956). Concept of general and specific combining ability in relation to diallel crossing systems. Aust. J. Biol. Sci. 9: 463-493. https://doi.org/10.1071/BI9560463

Guo WL, Chen RG, Gong ZH, Yin YX, et al. (2012). Exogenous abscisic acid increases antioxidant enzymes and related gene expression in pepper (Capsicum annuиm) leaves subjected to chilling stress. Genet. Mol. Res. 11: 4063-4080. https://doi.org/10.4238/2012.September.10.5

Hazarika BN (2003). Acclimatization of tissue-cultured plants. Curr. Sci. 85: 1704-1712.

Hatzig SV, Frisch M, Breuer F, Nesi N, et al. (2015). Genome-wide association mapping unravels the genetic control of seed germination and vigor in Brassica napus. Front. Plant Sci. 6: 221. https://doi.org/10.3389/fpls.2015.00221

Jinks JL and Pooni HS (1976). Predicting the properties of recombinant inbred lines derived by single seed descent. Heredity 36: 253-266. https://doi.org/10.1038/hdy.1976.30

Lazar MD, Baenziger PS and Schaeffer GW (1984). Combining abilities and heritability of callus formation and plantlet regeneration in wheat (Triticum aestivum L.) anther cultures. Theor. Appl. Genet. 68: 131-134.

Genetics and Molecular Research 16 (3): gmr16038869 
Medeiros GDA, Rêgo ER, Barroso PA, Ferreira KTC, et al. (2015). Heritability of traits related to germination and morphogenesis in vitro in ornamental peppers. Acta Hortic. 1087: 403-408. https://doi.org/10.17660/ ActaHortic.2015.1087.54

Mok SH and Norzulaani K (2007). Trouble shooting for recalcitrant bud formation in Capsicum annuum var. Kulai. Asia Pac. J. Mol. Biol. Biotechnol. 15: 33-38.

Murashigue T and Skoog F (1962). A revised medium for rapid growth and bioassays with tobacco tissue cultures. Physiol. Plant. 15: 473-497. https://doi.org/10.1111/j.1399-3054.1962.tb08052.x

Nascimento NF, do Rêgo ER, Nascimento MF, Bruckner CH, et al. (2014). Combining ability for yield and fruit quality in the pepper Capsicum annuum. Genet. Mol. Res. 13: 3237-3249. https://doi.org/10.4238/2014.April.29.2

Nascimento NFF, Rêgo ER, Rêgo MM, Nascimento MF, et al. (2012). Compatibilidade em cruzamentos intra e interespecíficos em pimenteiras ornamentais. Rev. Bras. Hortic. Ornam. 18: 57-51.

Neitzke RS, Fischer SZ, Vasconcelos CS, Barbieri RL, et al. (2016). Ornamental peppers: acceptance and preferences by consumers. Horticult. Bras. 34: 102-109.

Ochoa-Alejo N and Ramirez-Malagon R (2001). In vitro chili pepper biotechnology. In Vitro Cell. Dev. Biol. Plant 37: 701-729. https://doi.org/10.1007/s11627-001-0121-z

Powell W and Caligari PDS (1987). The in vitro genetics of barley (Hordeum vulgare L.): detection and analysis of reciprocal differences for culture response to 2, 4-dichlorophenoxyacetic acid. Heredity 59: 293-299. https://doi. org/10.1038/hdy.1987.126

Powell W, Caligari PDS, McNicol JW and Jinks JL (1985). The use of doubled haploids in barley breeding. 3. An assessment of multivariate cross prediction methods. Heredity 55: 249-254. https://doi.org/10.1038/hdy.1985.98

Pratta G, Cánepa LN, Zorzoli R and Picardi LA (2003). Diallel analysis of in vitro culture traits in the genus Lycopersicon. HortScience 38: 110-112.

Rêgo ER, Rêgo MM, Finger FL and Cruz CD (2009). A diallel study of yield components and fruit quality in chilli pepper (Capsicum baccatum). Euphytica 168: 275-287. https://doi.org/10.1007/s10681-009-9947-y

Rêgo ER, Finger FL and Rêgo MM (2016). Production and Breeding of Chilli Peppers (Capsicum spp.). Springer, 134.

Rêgo ER, Rêgo MM, Finger FL and Cruz CD (2015a). Methodological Basis and Advances for Ornamental Pepper Breeding Program in Brazil. Acta Hortic. 309-314. https://doi.org/10.17660/ActaHortic.2015.1087.39

Rêgo MM, Barroso PA, Rêgo ER, Santos WS, et al. (2015b). Diallelic analysis during in vitro seed germination in ornamental chili pepper. Acta Hortic. 1099: 765-769. https://doi.org/10.17660/ActaHortic.2015.1099.96

Roca WM, Arias DI and Chavéz R (1991). Métodos de conservación in vitro del germoplasma. In: Cultivo de tejidos en la agricultura: fundamentos y aplicaciones (Roca WM and Mroginski LA, eds.). Centro Internacional de Agricultura Tropical, Cali, 697-712.

Rolando GG, Quiroz K, Carrasco B and Caligari P (2010). Plant tissue culture: Current status, opportunities and challenges. Cienc. Investig. Agrar. 37: 5-30. https://doi.org/10.4067/S0718-16202010000300001

Rolland F, Moore B and Sheen J (2002). Sugar sensing and signaling in plants. Plant Cell 14 (Suppl): S185-S205.

Sarrafi A, Roustan JP, Fallot J and Alibert G (1996). Genetic analysis of organogenesis in the cotyledons of zygotic embryos of sunflower (Helianthus annuus L.). Theor. Appl. Genet. 92: 225-229. https://doi.org/10.1007/BF00223379

Schuelter AR, Pereira GM, Amaral Jr AT, Casali VW, et al. (2010). Genetic control of agronomically important traits of pepper fruits analyzed by Hayman's partial diallel cross scheme. Genet. Mol. Res. 9: 113-127. https://doi.org/10.4238/ vol9-1gmr694

Sparrow PAC, Townsend TM, Morgan CL, Dale PJ, et al. (2004). Genetic analysis of in vitro shoot regeneration from cotyledonary petioles of Brassica oleracea. Theor. Appl. Genet. 108: 1249-1255. https://doi.org/10.1007/s00122003-1539-y

Steinitz B, Wolf D, Matzevitch-Josef T and Zelcer A (1999). Regeneration in vitro and genetic transformation of pepper (Capsicum spp.): The current state of art. Capsicum Eggplant News Lett 18: 9-15.

Genetics and Molecular Research 16 (3): gmr16038869 